B. MRZYGŁÓD*\# ${ }^{*}$ A. KOWALSKI**, I. OLEJARCZYK-WOŻENSKA*,

T. GIĘTKA***, M. GŁOWACKI*

\title{
CHARACTERISTICS OF ADI DUCTILE CAST IRON WITH SINGLE ADDITION OF 1.56\% Ni
}

\begin{abstract}
The results of examinations of microstructure and an analysis of its impact on selected mechanical properties of austempered ductile iron (ADI) were presented in the paper. The ADI was produced from the ductile iron containing $1.56 \%$ Ni only alloying addition. The effect of the austempering time and temperature on the microstructure and mechanical properties of the examined cast iron was considered. Constant conditions of austenitizing were assumed and six variants of the austempering treatment were adopted. The studyof mechanical properties included a static tensile test, Charpy impact strength test and Brinellhardness measurement.

This work complements the knowledge about alloying additions effect on microstructure and mechanical properties of ADI and focuses on the impact of a single alloying element $(\mathrm{Ni})$.

Keywords: ductile iron, heat treatment, the structure of ADI, ADI properties
\end{abstract}

\section{Introduction}

ADI (Austempered Ductile Iron) is a modern, low-alloy ductile iron subjected to the austempering treatment. The chemical composition of the base cast iron is similar to a conventional ductile iron with $3.6 \% \mathrm{C}, 2.5 \% \mathrm{Si}$, up to $0.3 \% \mathrm{Mn}$, up to $0.015 \% \mathrm{~S}$ and up to $0.06 \% \mathrm{P}$. The alloying elements such as $\mathrm{Cu}$, $\mathrm{Ni}, \mathrm{Mo}, \mathrm{Mn}$ are introduced to enhance the ability of cast iron to form an ausferritic microstructure during the process of ausferritizing.

Ausferrite is the metal matrix microstructure composed of a homogeneous lamellar ferrite in the form of "needles" and thermodynamically stable austenite with high carbon content $(1.6-2.2 \% \mathrm{C})$. This structure confers to the ADI a favourable combination of high strength, ductility, fracture toughness and abrasive wear resistance.

Compared with steel, ADI has a number of advantages, making it attractive to designers. The most important are [1]:

- better as-cast machinability,

- $\quad$ higher damping capacity,

- lower risk of scuffing,

- lower notch sensitivity,

- higher dimensional stability after heat treatment,

- lower energy consumption during production of machine parts.

Recently, ADI has been more and more popular as a substitute for aluminium products, and this is due to the following reasons [2]:
- three times higher strength than the strength of aluminium for density only 2.6 times greater, which means that with proper design of an element, a reduction in its weight becomes quite realistic,

- often even 10 times lower price than that of aluminium, meaning evident cost savings,

- higher dimensional accuracy after casting and better reproduction of shapes, which results in higher metal yield expressed as the ratio of metal cast to metal sold in the form of castings,

- much higher fatigue strength,

- better damping capacity,

- $\quad$ higher resistance to abrasive wear.

The process of making castings from ADI consists of two main stages:

- proper selection of the chemical composition and manufacture of castings,

- austempering conducted according to the pre-established regime.

Although the technical literature on the chemical composition of ADI is very abundant, studies continue in search for an optimum content of the alloying elements.

Past experience shows that the most commonly used are the following combinations of the additives:

- $\quad \mathrm{Ni}-\mathrm{Mo}[3]$,

$-\mathrm{Ni}-\mathrm{Cu}[4,5]$,

- $\mathrm{Mn}-\mathrm{Cu}[6]$,

- $\mathrm{Ni}-\mathrm{Mo}-\mathrm{Cu}[7]$

* AGH UNIVERSITY OF SCIENCE AND TECHNOLOGY, FACULTY OF METALS ENGINEERING AND INDUSTRIAL COMPUTER SCIENCE, AL. A. MICKIEWICZA 30, 30-059 KRAKÓW, POLAND ** FOUNDRY RESEARCH INSTITUTE, 73 ZAKOPIAŃSKA STR., 30-418 KRAKÓW, POLAND

*** UTP UNIVERSITY OF SCIENCE AND TECHNOLOGY, FACULTY OF MECHANICAL ENGINEERING, 7 PROF. S. KALISKIEGO AV., 85-796 BYDGOSZCZ, POLAND

\# Corresponding author: mrzyglod@agh.edu.pl 
Tests also cover ADI with single additions of:

chromium [8]

manganese $[9,10]$

boron [11]

On the other hand, the literature lacks the data on the ADI with nickel added as a single element. Studies of this subject have been undertaken in the present work and are expected to make a contribution and fill at least partially the existing gap.

In addition to cognitive elements, the authors of this study also tried to keep in mind the economic aspects, including a reduction in the content of the alloying elements added to cast iron and shortening the time of heat treatment.

The results of the study can also be used as a source of knowledge in computer systems that are developed for predicting the structure and properties of alloys after casting process [12-15]

\section{Test materials and methods}

\subsection{Test material}

Ductile iron of the chemical composition given in Table 1 was used in this study. Melting was performed at the Foundry Research Institute in Cracow using a RADYNE medium frequency induction furnace with crucible of $100 \mathrm{~kg}$ capacity and an inert lining. The spheroidizing treatment was performed by Sandwich method. All these operations were made in a slender ladle at $1400^{\circ} \mathrm{C}$. From the manufactured ductile iron, test coupons were cast according to ASTM A897 standard.

TABLE 1

Chemical composition of the tested ductile iron

\begin{tabular}{|c|c|c|c|c|c|c|}
\hline \hline \multicolumn{7}{|c|}{ Elements, wt\% } \\
\hline $\mathbf{C}$ & $\mathbf{S i}$ & $\mathbf{M n}$ & $\mathbf{M g}$ & $\mathbf{P}$ & $\mathbf{S}$ & $\mathbf{N i}$ \\
\hline 3.55 & 2.55 & 0.31 & 0.063 & 0.025 & 0.009 & 1.56 \\
\hline
\end{tabular}

\subsection{Determination of heat treatment parameters based on the results of dilatometric studies}

For dilatometric studies, 15 ductile iron samples with dimensions of $\phi 3 \times 10 \mathrm{~mm}$ were cut out. Dilatometric tests (dilatometer L78 RITA) comprised heating the samples to a temperature of $1100^{\circ} \mathrm{C}$ at a rate of $0.08^{\circ} \mathrm{C} / \mathrm{s}$ and plotting of respective dilatographs to determine the values of critical temperature $\left(A_{c 3}, A_{c 1 s}\right)$. Then, one cycle of the continuous cooling at a rate of $100^{\circ} \mathrm{C} / \mathrm{s}$ to ambient temperature was run to determine the $M_{S}$ point. The next phase of the work included dilatometric analysis of samples held under isothermal conditions in the temperature range of $700-300^{\circ} \mathrm{C}$.

Dilatometric studies and the TTT diagram obtained as a result of these studies (Fig. 1) allowed planning the heat treatment parameters (time and temperature of austenitizing and austempering). Constant austenitizing conditions (temperature: $T_{\gamma}=920^{\circ} \mathrm{C}$, time: $\tau_{\gamma}=120 \mathrm{~min}$ ) were selected and 12 variants of austempering were established. Choosing the temperatures of isothermal holding, the area of the occurrence of bainitic transformation was divided into two ranges, i.e. the upper range and lower range. For each of the ranges, three values of the temperature and two times of the austempering were selected, different for the lower and upper range. Samples for the strength and toughness tests were austempered according to conditions presented in Table 2 and illustrated by diagram shown in Fig. 2.

The applied variants of austempering treatment and their reference numbers are shown in Table 2.

Each single variant of the austenitizing and austempering treatment included three test pieces prepared for the impact test and three test pieces prepared for the tensile test. Heat treatment was carried out in the Department of Ferrous Alloys at the Foundry Research Institute in Cracow. Austenitizing was made in a NABERTHERM Multitherm N41/M furnace with a tight retort and a protective atmosphere of inert gas to prevent decarburizing of the sample surface. Samples were heated with the furnace to $920^{\circ} \mathrm{C}$ and held at that temperature

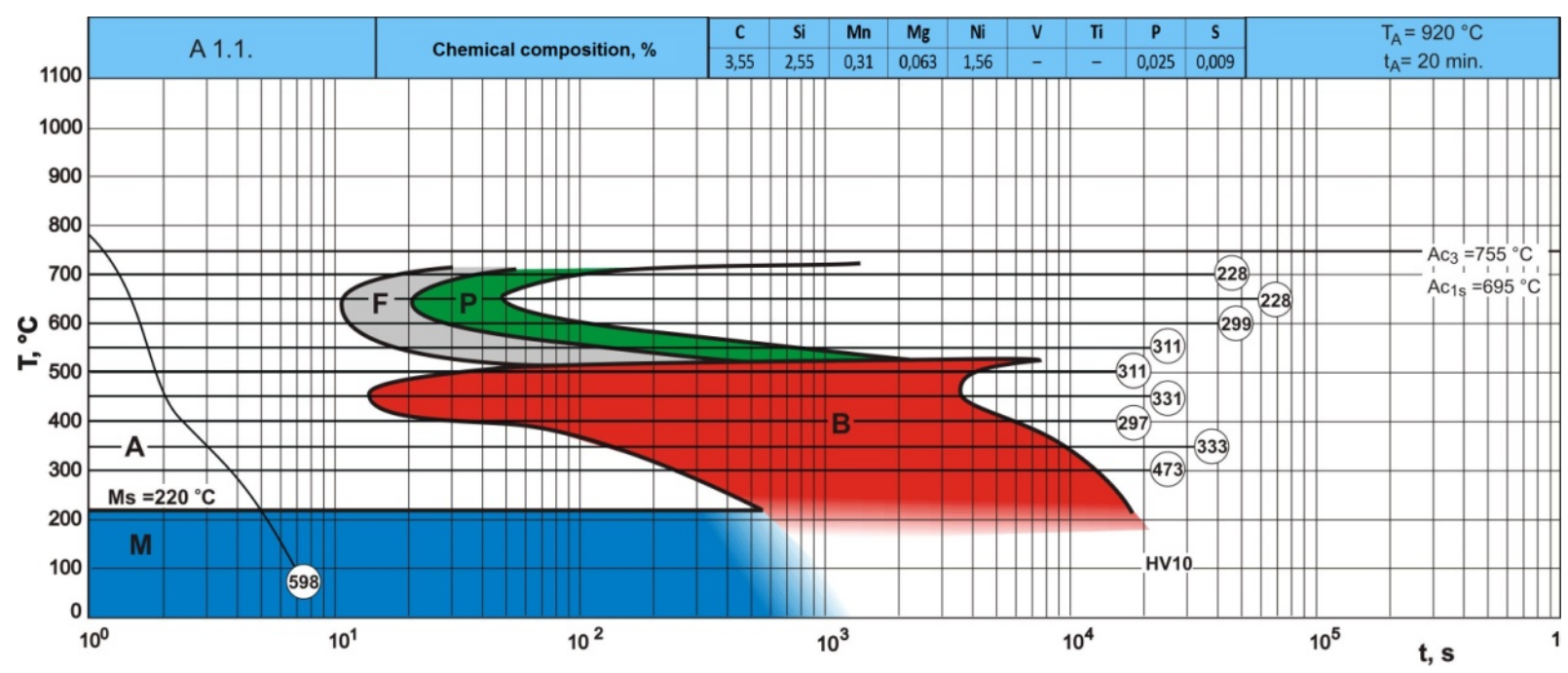

Fig. 1. TTT diagram of examined ductile cast iron 


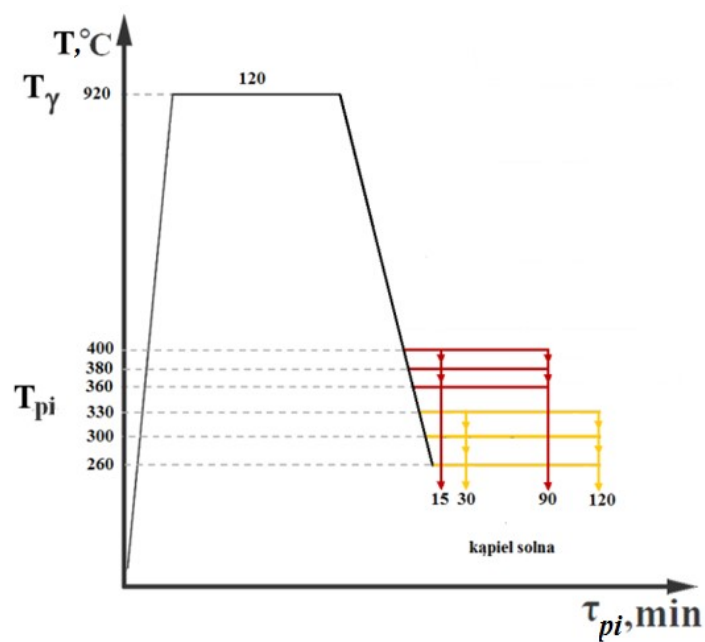

Fig. 2. Variants of the austempering treatment

TABLE 2

Variants of the austempering treatment

\begin{tabular}{|c|c|c|c|c|c|}
\hline \hline Variant & $\begin{array}{c}\text { Austempe- } \\
\text { ring } \\
\text { temperature } \\
\boldsymbol{T}_{p i}\left[{ }^{\circ} \mathbf{C}\right]\end{array}$ & $\begin{array}{c}\text { Austem- } \\
\text { pering } \\
\text { Time } \\
\boldsymbol{\tau}_{\boldsymbol{p} i}[\mathbf{m i n}]\end{array}$ & Variant & $\begin{array}{c}\text { Austempe- } \\
\text { ring } \\
\text { temperature } \\
\left.\boldsymbol{T}_{\boldsymbol{p} i}{ }^{\circ} \mathbf{C}\right]\end{array}$ & $\begin{array}{c}\text { Austem- } \\
\text { pering } \\
\text { time } \\
\boldsymbol{\tau}_{\boldsymbol{p} \boldsymbol{i}}[\mathbf{m i n}]\end{array}$ \\
\hline W11 & 400 & 15 & $\mathbf{W 1 2}$ & 400 & 90 \\
\hline W9 & 380 & 15 & $\mathbf{W 1 0}$ & 380 & 90 \\
\hline W7 & 360 & 15 & $\mathbf{W 8}$ & 360 & 90 \\
\hline W5 & 330 & 30 & $\mathbf{W 6}$ & 330 & 120 \\
\hline W3 & 300 & 30 & $\mathbf{W 4}$ & 300 & 120 \\
\hline W1 & 260 & 30 & $\mathbf{W} 2$ & 260 & 120 \\
\hline
\end{tabular}

for $2 \mathrm{~h}$. A protective atmosphere of compressed argon was used in the furnace.

Austempering (ausferritizing) was carried out in a salt bath consisting of a mixture of potassium nitrate and sodium nitrite. The salt bath temperature and isothermal cooling times are shown in Table 2.

\subsection{Microstructure of base ductile iron and ADI after different variants of the austempering treatment}

To reveal the microstructure of the test material, metallographic sections of both base ductile iron and ADI after different heat treatment variants were prepared. The metallographic sections of base cast iron and of cast iron after heat treatment were etched in the Mi1Fe reagent according to PN-61/H-04503. Selected metallographic sections of ADI were also etched in the B-M reagent of the following chemical composition: $100 \mathrm{ml}$ of base solution ( 5 parts by volume of $\mathrm{H}_{2} \mathrm{O}, 1$ part by volume of concentrated $\mathrm{HCl}$ ), $2 \mathrm{~g}$ of $\mathrm{NH}_{4} \mathrm{~F} \cdot \mathrm{HF}, 1 \mathrm{~g}$ of $\mathrm{K}_{2} \mathrm{~S}_{2} \mathrm{O}_{5}$. This reagent does not dye austenite and carbides, while bainite and tempered martensite are coloured in brown, and martensite is coloured in blue. Sometimes fine martensite needles assume not a blue but light brown colour, and if this is the case, then the assessment of microstructure should be based on the studies of its morphology.

Microstructure in both as-cast state and after heat treatment was examined with an AXIO OBSERVER Z1M metallographic microscope.

\subsection{Testing of mechanical properties}

Testing of mechanical properties included:

- $\quad$ static tensile test carried out at ambient temperature on an Instron 8502 type testing machine. The cut out test pieces were prepared in accordance with PN EN 1564. Tests consisted in loading at a constant speed the samples mounted in chucks of a hydraulic testing machine. The speed of the tensile test was $0.02 \mathrm{~mm} / \mathrm{s}$. The elongation of the sample was measured with an extensometer mounted on a measuring section of the sample. During tensile tests, the instantaneous values of the loading force and elongation of the sample were recorded. The tensile test was carried out until the sample fracture. The parameters determined included the tensile strength $R_{m}$, yield strength $R_{p 0.2}$ and elongation $A_{5}$. The results of the strength measurements were recorded on three samples taken for a given heat treatment variant, calculating next the mean values.

- measurement of the Charpy impact strength at ambient temperature. The measurement of impact strength was performed on $55 \times 10 \times 10 \mathrm{~mm}$ samples V-notched to a depth of $2 \mathrm{~mm}$ and with a fillet radius of $0.25 \mathrm{~mm}$. To carry out the tests, Charpy pendulum was used. The results of impact test measurements were recorded on three samples taken for a given heat treatment variant, calculating next the mean values.

- Brinell hardness measurement. Brinell hardness measurements were taken using an INNOVATEST/Nexus 703A hardness tester. The test consisted in pressing a calibrated $D=2.5 \mathrm{~mm}$ diameter ball into the polished surface of the sample at a load of $P=187.5 \mathrm{~kg}$. The operation time of full pressure was $15 \mathrm{~s}$. Hardness measurements were conducted on samples broken in the impact test. For each variant, 15 Brinell hardness measurements were taken, calculating next the mean.

\section{Test results}

\subsection{As-cast microstructure}

Images of as-cast ductile iron microstructure are shown in Fig. 3. The microstructure is composed of metal matrix with particles of spheroidal graphite distributed in this matrix. Most of the graphite particles are surrounded by polygonal ferrite grains. The metal matrix is formed of pearlite, inside which occasionally occur ferrite grains and particles of non-metallic inclusions. 

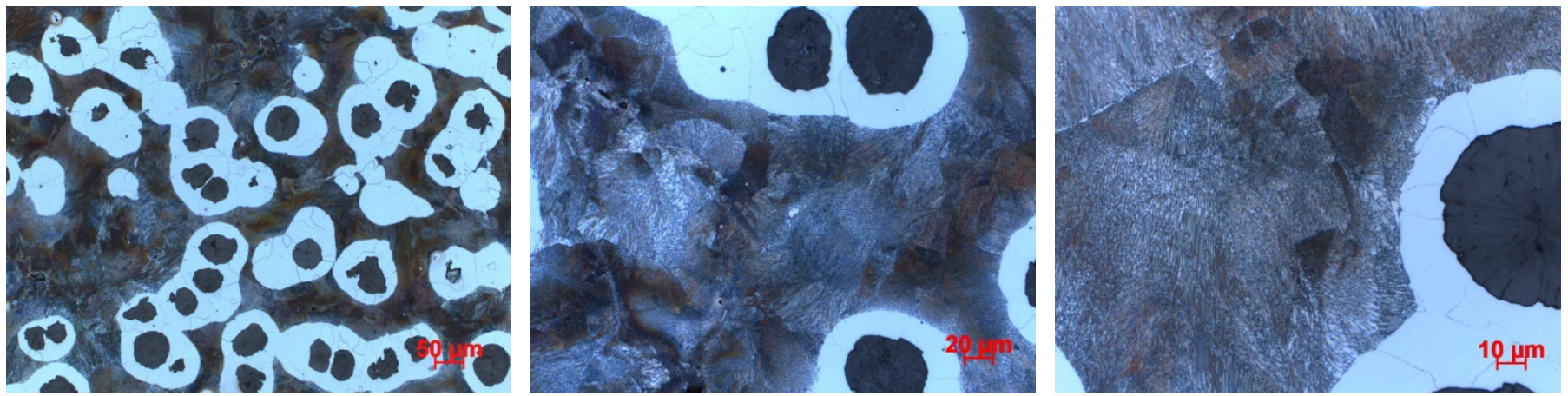

Fig. 3. As-cast microstructure of the tested cast iron

\subsection{Microstructure of ADI after different variants of the austempering treatment}

The photos of microstructure in Table 3 illustrate the effect of the time and temperature of bainitic transformation on the ADI matrix. As regards the temperature of the transformation, it is clear that the higher is this temperature, the longer and thicker are the "needles" of ferrite, and the higher is the austenite content, reaching at $380-400^{\circ} \mathrm{C}$ even $30 \%$. This type of ADI has a very high ductility (Table 4). On the other hand, austempering in the range of $260-300^{\circ} \mathrm{C}$ significantly increases both strength and hardness of this material (Table 4). The austempering time of 15 minutes is definitely far too short and not used in practice. In this study it was used only for cognitive reasons. The photos of microstructure show that with the time of treatment so short, complete bainitic transformation is not possible.

The austempering time of 90 minutes is applicable in the case of austempering treatment ranging from 360 to $400^{\circ} \mathrm{C}$, while the time of 120 minutes (and longer) gives satisfactory results when the treatment is carried out in the temperature range of $260-300^{\circ} \mathrm{C}$.

Both theory and practice show that this is related to the rate of carbon diffusion, which at higher temperatures of the bainitic transformation is proceeding more quickly, and more slowly at lower temperatures.

It should be emphasized that studies were conducted on samples of $10 \mathrm{~mm}$, tested for the mechanical strength. Castings with thicker walls usually require longer times of austempering.

TABLE 3

Microstructure of material after different variants of the austempering treatment

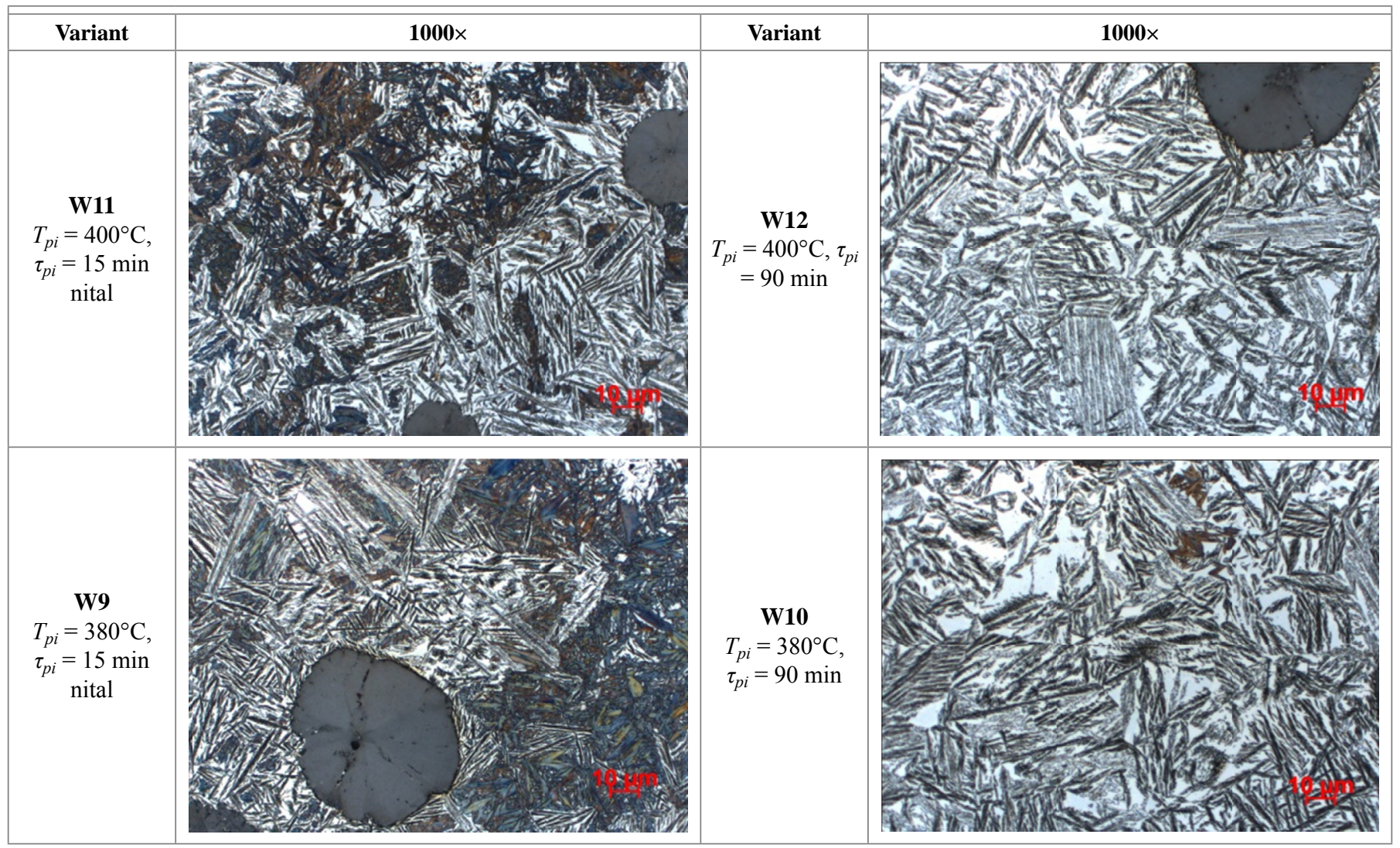




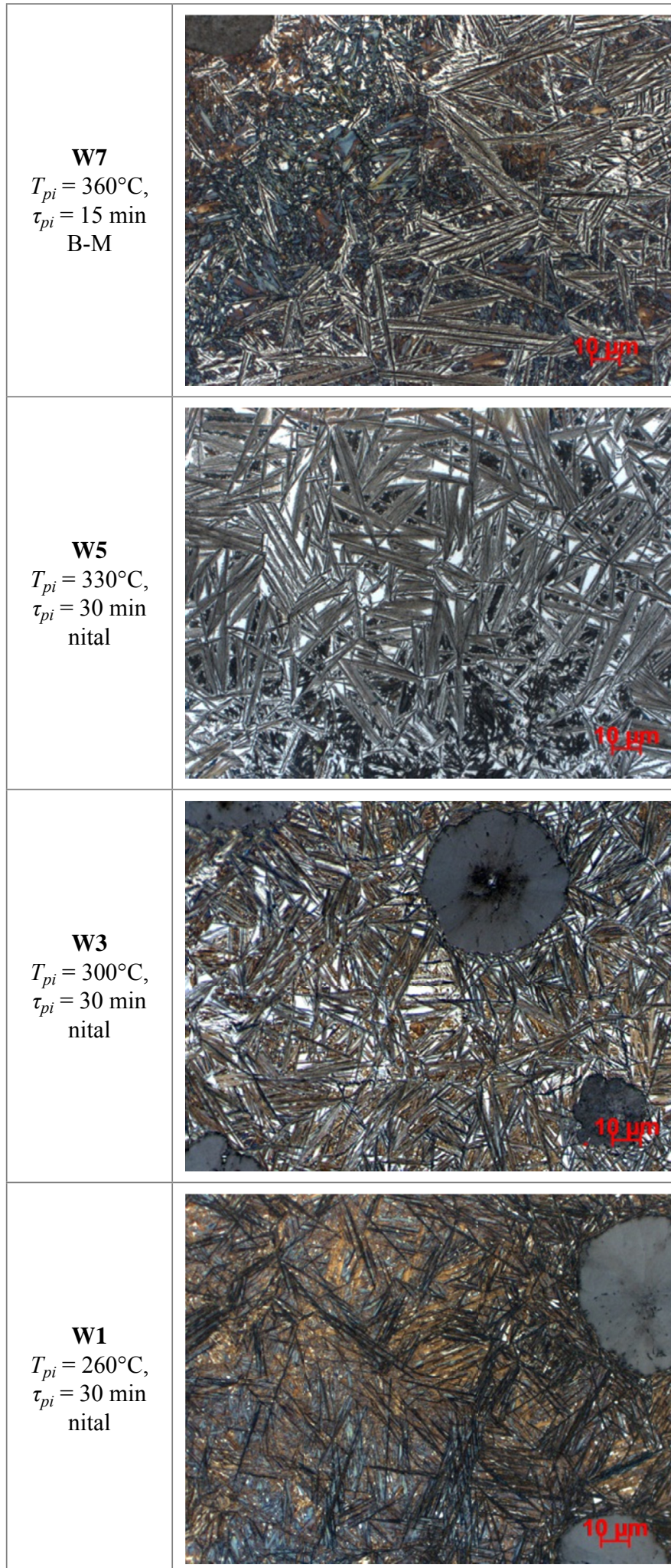

\subsection{The results of mechanical tests}

\subsubsection{Static tensile test}

The following as-cast mechanical properties of the ductile iron were obtained: the yield strength $R_{p 0,2}=478 \mathrm{MPa}$, the tensile strength $R_{m}=701 \mathrm{MPa}$ and elongation $A_{5}=6.9 \%$.

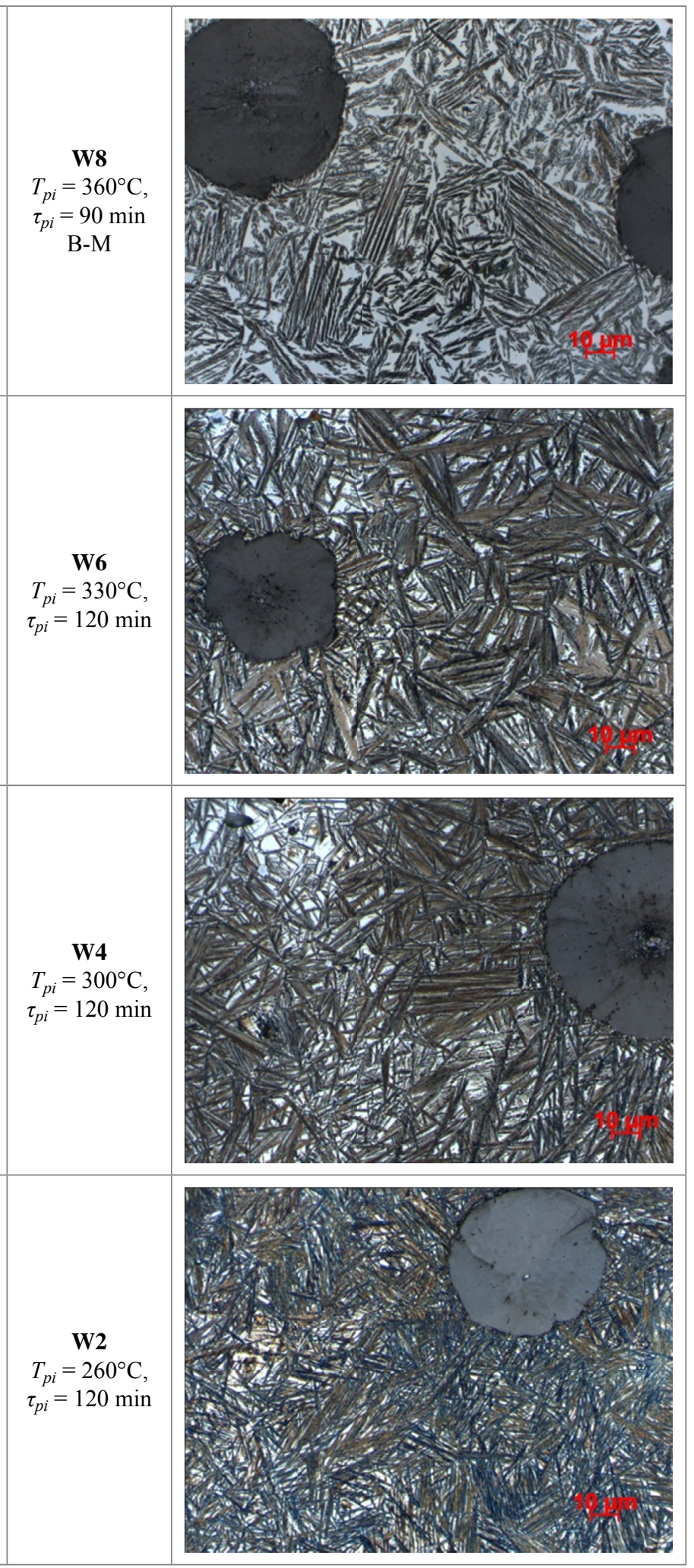

Table 4 gives the results obtained in the static tensile test carried out on specimens heat-treated according to the proposed variants. The values given in Table 4 are the arithmetic mean values calculated from the measurements taken on three samples. 
TABLE 4 are the mean calculated from the measurements taken on three

The results of mechanical tests

\begin{tabular}{|c|c|c|c|c|c|c|c|}
\hline Variant & $A_{5}, \%$ & $\begin{array}{c}R_{m}, \\
\text { MPa }\end{array}$ & $\begin{array}{l}R_{p 0,2}, \\
\text { MPa }\end{array}$ & Variant & $A_{5}, \%$ & $\begin{array}{c}R_{m}, \\
\mathrm{MPa}\end{array}$ & $\begin{array}{l}R_{p 0,2}, \\
\text { MPa }\end{array}$ \\
\hline W11 & 1,8 & 868 & 595 & W12 & 7,8 & 950 & 597 \\
\hline W9 & 1,8 & 810 & 675 & W10 & 4,9 & 960 & 681 \\
\hline W7 & 1,3 & 952 & 757 & W8 & 6,0 & 1068 & 783 \\
\hline W5 & 2,4 & 1201 & 779 & W6 & 4,2 & 1255 & 968 \\
\hline W3 & 1,4 & 1065 & 835 & W4 & 3,9 & 1381 & 1017 \\
\hline W1 & 1,1 & 737 & & W2 & 2,0 & 1343 & 1343 \\
\hline
\end{tabular}

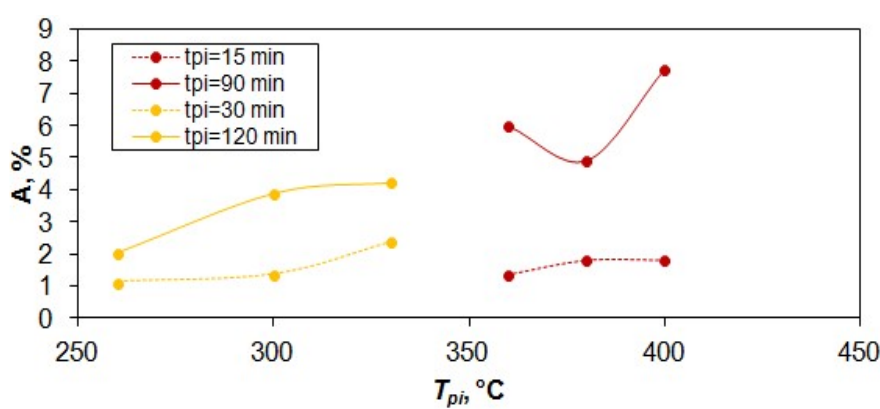

Fig. 4. ADI impact elongation vs the time and temperature of austempering

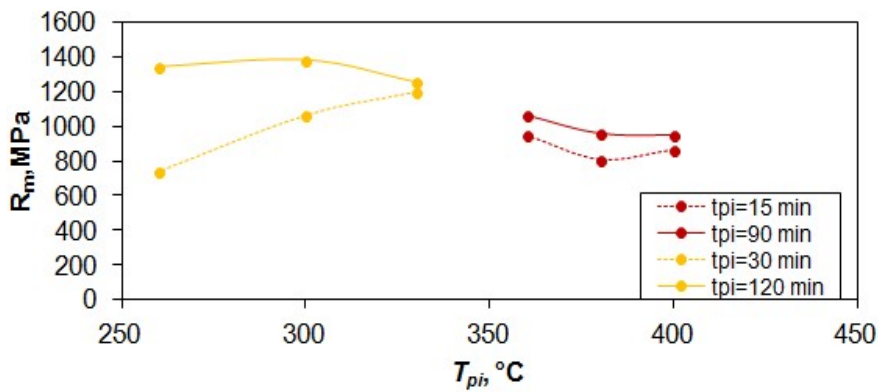

Fig. 5. ADI tensile strength vs the time and temperature of austempering

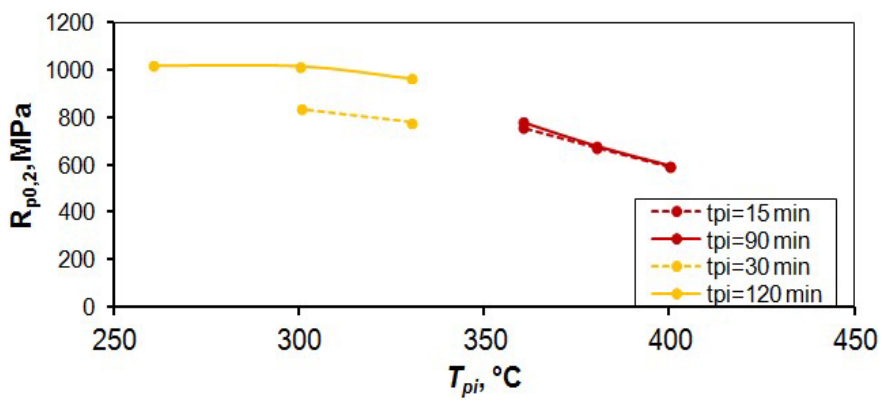

Fig. 6. ADI yield strength vs the time and temperature of austempering

\subsubsection{Hardness}

As-cast hardness of the ductile iron was $202 \mathrm{HB}$. Table 5 gives the results of hardness measurements for samples heat treated according to Figure 2 Austempering diagram. The results samples.

TABLE 5

The results of hardness measurements

\begin{tabular}{|c|c|c|c|}
\hline \hline Variant & HB & Variant & HB \\
\hline W11 & 292 & W12 & 270 \\
\hline W9 & 369 & W10 & 285 \\
\hline W7 & 401 & W8 & 325 \\
\hline W5 & 375 & W6 & 371 \\
\hline W3 & 437 & W4 & 392 \\
\hline W1 & 523 & W2 & 452 \\
\hline
\end{tabular}

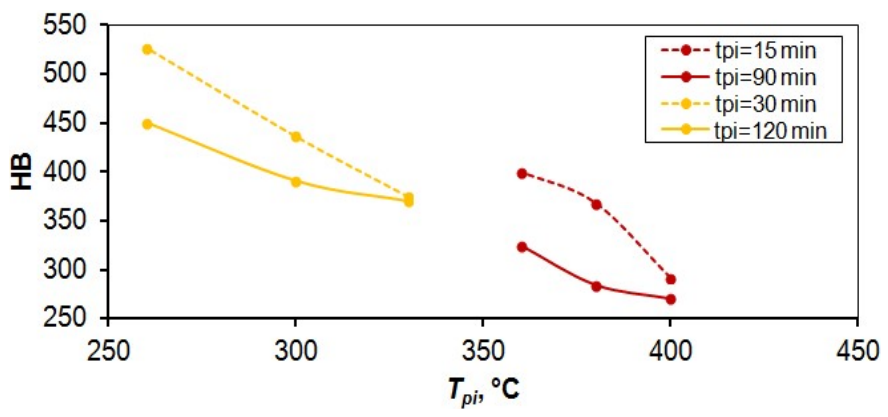

Fig. 7. ADI hardness vs the time and temperature of austempering

\subsubsection{Impact strength}

As-cast impact strength of the ductile iron was $\mathrm{KCV}=$ $4.2 \mathrm{~J} / \mathrm{cm}^{2}$. The results of impact tests obtained on the heat treated samples are shown in Table 6. For each variant, the mean was calculated from the measurements taken on three samples.

TABLE 6

The results of impact tests

\begin{tabular}{|c|c|c|c|}
\hline \hline Variant & $\mathbf{K C V}, \mathbf{J} / \mathbf{c m}^{\mathbf{2}}$ & Variant & $\mathbf{K C V}, \mathbf{J} / \mathbf{c m}^{\mathbf{2}}$ \\
\hline W11 & 4,8 & W12 & 11,9 \\
\hline W9 & 3,8 & W10 & 11,5 \\
\hline W7 & 3,4 & W8 & 10,7 \\
\hline W5 & 6,3 & W6 & 9,9 \\
\hline W3 & 5,5 & W4 & 8,1 \\
\hline W1 & 2,4 & W2 & 6,8 \\
\hline
\end{tabular}

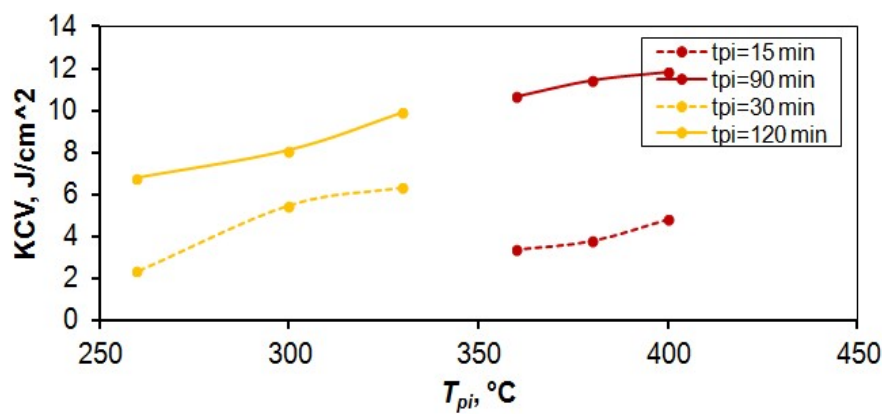

Fig. 8. ADI impact strength vs Austempering time and temperature 


\section{Discussion}

\section{Base cast iron}

The analysis of obtained results indicate that:

- the chemical composition of the base cast iron is typical for pearlitic-ferritic ductile iron.

- pearlitic microstructure of the metal matrix and regular precipitates of the spheroidal graphite were obtained,

- $\quad$ high values of the strength and ductility were obtained, i.e. the yield strength $R_{p 0,2}=478 \mathrm{MPa}$, the tensile strength $R_{m}=701 \mathrm{MPa}$, elongation $A_{5}=6.9 \%$, Brinell hardness of $202 \mathrm{HB}$, the impact strength $\mathrm{KCV}=4.2 \mathrm{~J} / \mathrm{cm}^{2}$.

\section{TTT diagram}

To find correct parameters of the austempering treatment it is necessary to plot a TTT diagram. A diagram like this, plotted for the cast iron of the composition as demonstrated in Table 1, is shown in Figure 1. From the diagram it follows that the hardenability to ausferrite is in this case inferior to the hardenability obtained in the cast irons with two or three alloying elements.

\section{Austempering}

The adopted range of isothermal transformation was from 260 to $400^{\circ} \mathrm{C}$ at the time of austempering amounting to 15,30 , 90 and 120 minutes.

- $\quad$ ADI microstructure is shown in Table 4. There are clear differences in the size of ferrite "needles" and in the austenite content. The higher is the temperature of austempering, the thicker are the "needles" and the higher is the content of austenite.

- ADI strength achieves its peak values after austempering at 260,300 and $330^{\circ} \mathrm{C}$, i.e. 1343,1381 and $1255 \mathrm{MPa}$, respectively, at the elongation $A_{5}$ equal to $2.0,3.9$ and $4.2 \%$, respectively. This corresponds to the ADI grade 1200-2 according to PN EN 1564,

- hardness - the results of Brinell hardness measurements are given in Table 6 . The highest values of hardness were obtained in the cast iron austempered at $360^{\circ} \mathrm{C}$ (523 and $452 \mathrm{HB})$. This clearly indicates the presence of martensite in the structure. The presence of this constituent in the structure of ADI is disadvantageous, because it decreases the ductility and may cause embrittlement, unless the target is obtaining maximum abrasive wear resistance,

- impact strength, like the yield strength and elongation, is a measure of the ADI ductility, and thus of its fracture toughness. The results of these measurements are given in Table 7. The highest values of this property were obtained after austempering at $380^{\circ} \mathrm{C}(11.5 \mathrm{KCV})$ and $400^{\circ} \mathrm{C}(11.9$ $\mathrm{KCV})$. Yet, even after austempering at $300^{\circ} \mathrm{C}$, the impact strength of $8.1 \mathrm{KCV}$ was obtained, which was a very satisfactory result.

All of the above described properties are graphically depicted in the diagrams in (Figs. 6-10). Successive graphs illustrate the effect of the time and temperature of austempering on the tested mechanical properties.

\section{Summary}

Based on examinations results and their analysis several conclusions were formulated:

- the conducted tests and studies have shown that ADI with the addition of single alloying element, i.e. $1.5 \% \mathrm{Ni}$, can produce only the grades $800-8$ and $1200-2$ (according to PN EN 1624),

- $\quad$ optimum ausferritizing parameters for the grade $800-8$ are $380^{\circ} \mathrm{C}$ at the time of 90 minutes,

- optimum ausferritizing parameters for the grade 1200-2 are $300^{\circ} \mathrm{C}$ at the time of 120 minutes,

- the austempering times of 15 and 30 minutes are definitely too short,

- at the austempering temperature of $260^{\circ} \mathrm{C}$, an ausferriticmartensitic structure is obtained characterized by a hardness of over $400 \mathrm{HB}$ and high resistance to abrasive wear,

- $\quad$ ADI containing $1.5 \%$ Ni requires more detailed studies, including fatigue strength and fracture toughness.

\section{Acknowledgements}

Financial assistance of the NCN, project No. 2013/11/N/ST8/00326

\section{REFERENCES}

[1] C. Podrzucki, Problemy produkcji odlewów z żeliwa sferoidalnego ADI. Przegląd Odlewnictwa 10, 260-265 (1996).

[2] Multiple advantages of austempered ductile iron. ADI being chosen over aluminum. Modern Casting 9, 15-16 (1999).

[3] J.F. Janowak, P.A. Morton, A guide to mechanical properties possible by austempered $1,5 \% \mathrm{Ni}-0,3 \%$ Mo ductile iron. Transactions AFS, 489-498 (1984)

[4] M. Grech, J.M. Young, Impact properties of a Cu-Ni austempered ductile iron. Cast Metals 1/2, 98,(1988).

[5] A. Kowalski, J. Tybulczuk, Experience of The Foundry Research Institute Krakow in investigation and application of $\mathrm{Ni}-\mathrm{Cu} \mathrm{ADI}$ for castings. 42 Livarsko Strokovno Posvetovanje. Slovenja, Portoroż 23-24 May 2002, (2002).

[6] R.H. Juneja, et al., Austempering ductile iron alloyed with coper and manganese, Foundry 64, (1989).

[7] E. Dorazil, Zwischenstufenumwandeln von Gusseisen mit Kugelgraphit, Giesserei-Praxis 18, 355 (1979).

[8] K.L. Hayrynen, The production of austempered ductile iron (ADI). World Conference of ADI. Livonia, Michigan, USA, (2002).

[9] A. Owhadi, et al., Wear behavior of $1.5 \mathrm{Mn}$ austempered ductile iron, Materials Science and Technology 14, 245 (1998).

[10] M.N. Ahamadabadi, E. Niyama, T. Ohide, Structural control of $1 \% \mathrm{Mn}$ ADI aided by modeling of microsegregation, Transactions AFS, 269 (1994).

[11] Z. Pirowski, et al., Wpływ mikrododatku boru na zmiany hartowności w żeliwie sferoidalnym z przemianą izotermiczną w odniesieniu do odlewów grubościennych, Journal of Research 
and Applications in Agricultural Engineering 57 (2), 153-155, (2012).

[12] S. Kluska-Nawarecka, D. Wilk-Kołodziejczyk, K. Regulski, et al., Rough Sets Applied to the Rough Cast System for Steel Castings, Lecture Notes in Artificial Intelligence 6592, 52-61 (2011).

[13] B. Sniezynski, G. Legien, D. Wilk-Kolodziejczyk, et al., Creative Expert System: Result of Inference and Machine Learning Integration, Lecture Notes in Computer Science 9827, 257-271 (2016).
[14] D. Wilk-Kolodziejczyk, B. Mrzyglod, K. Regulski, et al., Influence of process parameters on the properties of austempered ductile iron (adi) examined with the use of data mining methods, Metalurgija 55 (4), 849-851 (2016).

[15] I. Olejarczyk-Wozenska, H. Adrian, B. Mrzygłód, et al., Numerical modelling of austenite-ferrite transformation in ADI, METAL 2015: 24th International Conference on Metallurgy And Materials, $810-815$ (2015). 